\title{
Promosi Kesehatan Pencegahan Hipertensi Sejak Dini
}

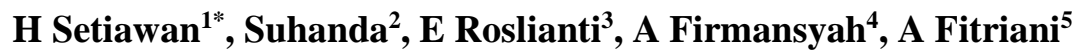 \\ ${ }^{12345}$ STIKes Muhammadiyah Ciamis
}

Email: ${ }^{1}$ henrisetiawan1989@gmail.com

\begin{abstract}
ABSTRAK
Hipertensi adalah kondisi tekanan darah lebih tinggi dari $140 / 90 \mathrm{mmHg}$. Hipertensi yang tidak terkontrol dapat menyebabkan berbagai macam penyakit hingga berujung kematian. Namun, pencegahan hipertensi dapat dilakukan sejak dini. Kegiatan Penyuluhan bertujuan untuk meningkatkan pengetahuan pelajar dan mahasiswa di Kabupaten Ciamis tentang pencegahan hipertensi. Kegiatan penyuluhan dilakukan dengan cara eksplanasi dan diskusi pada 130 pelajar dan mahasiswa di Kabupaten Ciamis yang dikumpulkan di Wisma Guru Ciamis pada tanggal 6 Maret 2018. Sebelum dan setelah penyuluhan, partisipan diberikan kuesioner pengetahuan dan hasilnya diolah menggunakan SPSS Versi 16. Instrumen penyuluhan menggunakan pamflet dan power point presentation. Penyuluhan pencegahan hipertensi sejak dini berlangsung dengan tertib dan lancar dan berdampak positif terhadap peningkatan pengetahuan pelajar dan masyarakat.
\end{abstract}

Kata Kunci: Promosi, Pencegahan, Hipertensi

\begin{abstract}
Hypertension is a condition which blood pressure is higher than 140/90 $\mathrm{mmHg}$. Uncontrolled hypertension can cause a variety of diseases to the point of death. However, prevention of hypertension can be done early. Health Promotions aim to increase the knowledge of students in Ciamis District about prevention of hypertension. Health Promotion were carried out by explanation and discussion of 130 students in Ciamis District who were collected at WISMA GURU Ciamis on March 6, 2018. Before and after Health Promotion, participants were given a knowledge questionnaire and the results were processed using SPSS Version 16. Health Promotion instruments used flyers and power point presentation. Health Promotion of prevention of hypertension early has done successful and has a positive impact on increasing the knowledge of students and society.
\end{abstract}

Keywords: Promotion, Prevention, Hypertension 


\section{PENDAHULUAN}

Hipertensi atau tekanan darah tinggi merupakan kondisi pembuluh darah secara persisten mengalami peningkatan tekanan (Lu et al., 2015). World Health Organization (WHO) pada tahun 2015 menyebutkan bahwa penderita hipertensi di dunia mencapai 1,13 Miliar orang dan hanya 36,8\% yang minum obat hipertensi. Sedangkan di Indonesia, prevalensi ini terus meningkat (Kementrian Kesehatan RI, 2018). Berdasarkan data Riset Kesehatan Dasar (RISKESDAS) peningakatan jumlah prevalensi penderita hipertensi di Indonesia dari tahun 2013 ke 2016 mencapai 32,4\%. Kondisi ini perlu mendapat perhatian lebih, karena hipertensi merupakan penyakit yang paling umum terjadi pada sistem kardiovaskuler yang dapat menyebabkan berbagai macam penyakit kronis seperti stroke, gagal jantung bahkan berakibat pada kematian (Gil-Extremera and Gómez-González, 2015).

Kekuatan tekanan darah sangat dipengaruhi oleh aktivitas dan banyak faktor lain meliputi faktor predisposisi dan presipitasi seperti umur dan jenis kelamin, riwayat keluarga, genetik, stress, obesitas dan gaya hidup seperti merokok, konsumsi alkohol, dan diet yang tidak sehat (Wang, Tiwari and Wang, 2014). Penelitian menunjukan bahwa resiko hipertiensi meningkat seiring bertambahnya usia. Pada perempuan, resiko hipertensi lebih tinggi dibandingkan dengan pria, hal ini sangat berhubungan dengan manajemen stress dan kekhasan karakter pada masing-masing jenis kelamin.

Hipertensi juga berhubungan dengan riwayat kesehatan keluarga yang melibatkan gen dan diwariskan mengikuti Mendelian Inheritance Pattern. Essential Hypertension hampir semua kromosom terlibat dalam pewarisan itu. Artinya, bila ada anggota keluarga yang mengalami hipertensi, sangat mungkin diwariskan dari generasi sebelumnya (Sarkar and Pal Singh, 2015).

Selain itu, fungsi hormonal mengalami perubahan yang akan mendorong peningkatan tekanan darah atau hipertensi pada saat seseorang mengalami stress. Stressor yang muncul akan merangsang otak untuk memproduksi Adeno Cortico Trophin Hormone (ACTH) lebih banyak, sehingga merangsang peningkatan produksi Cortisol Releasing Factor (CRF). Perubahan ini secara otomatis berdampak pada kadar kortisol yang meningkat dan menyebabkan perubahan hormon Angiostensin dan Aldosteron. Semua perubahan ini akan meningkatkan risiko hipertensi (Gold et al., 2005).

Konsumsi alkohol dan merokok adalah gaya hidup yang sangat buruk dan dapat meningkatkan rsisiko hipertensi. Studi ilmiah menunjukan, pengaruh rokok dan alkohol terhadap hipertensi sangat besar. Selain kandungan rokok dan alkohol sangat berbahaya, efek konsumsi keduanya dapat menimbulkan adiktif. Secara fisik dan psikologis tentu akan mengakibatkan penurunan kualitas kesehatan (Leone, 2015).

Pola makan yang salah, baik dari jumlah dan jenis makanan yang dikonsumsi beresiko tinggi meningkatkan hipertensi. Konsumsi makanan yang mengandung lemak dan kolesterol beresiko timbulnya plak yang menumpuk pada pembuluh darah, sehingga elastisitas pembuluh darah menjadi berkurang. Hal ini menjadi penyebab umum hipertensi pada pasien yang tidak memiliki riwayat keluarga hipertensi (Goyal and Sarwate, 2014).

Itulah beberapa penjelasan mengenai penyebab penyakit hipertensi. Selain faktor genetik, semua penyebab hipertensi dapat dicegah sejak dini. Pola hidup yang baik, manajemen stress yang tepat, serta olah raga secara teratur merupakan kunci hidup sehat yang dapat mencegah terjadinya hipertensi. Faktor pengetahuan dan sumber serta akses informasi yang cukup akan 
meningkatkan motivasi masyarakat khususnya pelajar dan mahasiswa untuk meningkatkan kualitas hidup dengan menghindari faktor-faktor penyebab hipertensi.

Salah satu upaya yang dilakukan untuk meningkatkan pengetahuan pelajar dan mahasiswa tentang pencegahan hipertensi adalah dengan melakukan penyuluhan sebagai bagian dari promosi kesehatan yang dilaksanakan oleh perawat selain upaya preventif, rehabilitatif dan kuratif (Hong, 2010).

\section{METODE}

Kegiatan penyuluhan dilakukan dengan cara eksplanasi dan diskusi pada 130 pelajar dan mahasiswa di Kabupaten Ciamis yang dikumpulkan di Wisma Guru Ciamis pada tanggal 6 Maret 2018 yang diundang melalui undangan secara terbuka via media sosial. Sebelum dan setelah penyuluhan, partisipan diberikan kuesioner untuk mengukur perubahan tingkat pengetahuan dan hasilnya berupa daya yang diolah menggunakan SPSS Versi 16.

Instrumen penyuluhan menggunakan pamflet dan power point presentation yang berisi tentang penjelasan penyakit hipertensi, meliputi definisi, etiologi, manifestasi klinis, penatalaksanaan dan pencegahan dini secara tepat.

\section{HASIL}

Hasil dari kegiatan pengabdian kepada masyarakat berupa promosi kesehatan pencegahan hipertensi sejak dini adalah peningkatan pengetahuan partisipan yang dibuktikan dengan perubahan skor kuesioner seperti disajikan pada gambar 1 .

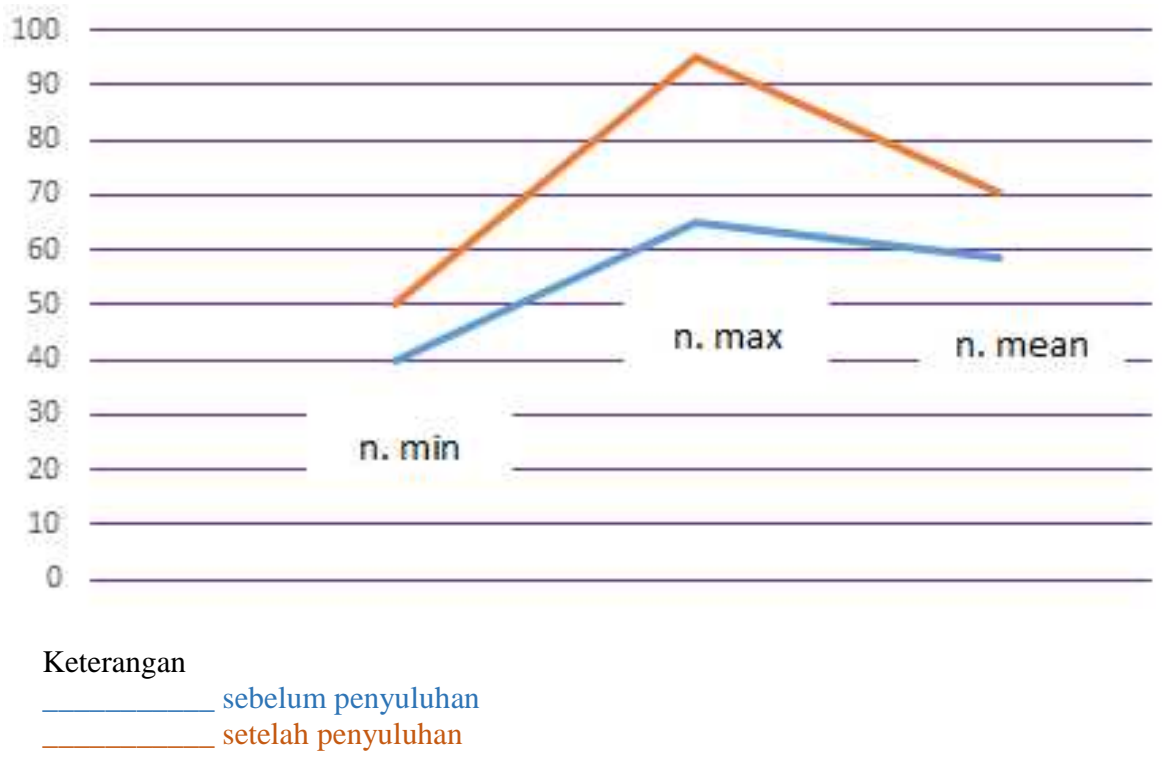

Gambar 1. Perubahan tingkat Pengetahuan Partisipasi tentang Hipertensi

Berdasarkan data yang disajikan pada diagram diatas, terdapat perubahan pengetahuan partisipan pada kegiatan promosi kesehatan ini. Sebelum promosi dilakukan, skor mean kuesioner adalah 58,68 dan setelah promosi dilakukan berubah skkor mean menjadi 70,20. 


\section{PEMBAHASAN}

Dalam meningkatkan derajat kesehatan masyarakat, perawat memiliki peran penting dengan melakukan upaya preventif, promotif, rehabilitatif dan kuratif. Preventif adalah upaya pencegahan terhadap suatu penyakit yang dapat menurunkan derajat kesehatan masyarakat, sedangkan promotif berupaya meningkatkan pengetahuan masyarakat tentang suatu penyakit sehingga meningkatkan motivasi untuk mencegah terjadinya penyakit tersebut (Hong, 2010).

Upaya promotif berkaitan erat dengan proses perubahan perilaku pada masyarakat dalam meningkatkan derajat kesehatan (Nadra, 2017). Mengubah perilaku masyarakat bukanlah hal yang mudah, butuh waktu yang cukup lama untuk memberikan kefahaman terhadap suatu penyakit sampai tumbuh kesadaran untuk mencegahnya sejak dini. Banyak penyakit muncul disebabkan oleh perilaku masyarakat yang tidak sehat, atau pola hidup yang tidak sehat, diantaranya hipertensi.

Hipertensi dapat dicegah dengan pola makan yang sehat, manajemen stress yang tepat, tidak mengkonsumsi alkohol dan tidak merokok. Dan pola hidup seperti ini perlu didorong melalui program promosi kesehatan.

Promosi kesehatan pencegahan hipertensi sejak dini sangat tepat diberikan kepada pelajar dan mahasiswa karena pada masa tersebut saatnya belajar mengetahui, memahami, menganalisis, sampai akhirnya mensintesa. Output dari proses pikir tersebut diharapkan terinternalisasi sehingga tumbuh kesadaran dan motivasi untuk mengubah prilaku yang tidak sehat yang dapat meningkatkan resiko terjadinya hipertensi. Merokok dan mengkonsumsi alkohol yang merupakan bentuk-bentuk kenakalan remaja dan berdampak buruk terhadap kesehatan tubuh, terutama meningkatkan resiko hipertensi dapat dicegah melalui promosi kesehatan tersebut.

\section{KESIMPULAN}

Kegiatan promosi kesehatan pencegahan hipertensi sejak dini berlangsung dengan lancar dengan pencapaian tujuan peningkatan pengetahuan partisipan dari mean $_{\text {pre }}=58,68$ menjadi mean $_{\text {post }}=70,20$. Kegiatan ini perlu dilanjutkan secara berkesinambungan dengan beberapa perbaikan seperti penggunaan alat peraga yang lebih atraktif, informatif dan edukatif. Sehingga beberapa proses fisiologis hipertensi dapat dilihat kasat mata.

Ucapan terima kasih disampaikan kepada Ketua STIKes Muhammadiyah Ciamis yang memfasilitiasi kegiatan pengabdian kepada masyarakat ini dari sisi anggaran. Juga kepada kepala dinas Pendidikan Kabupaten Ciamis yang memberikan izin rekomendasi sehingga kegiatan berlangsung dengan tertib.

\section{DAFTAR PUSTAKA}

Gil-Extremera, B. and Gómez-González, J. V. (2015) 'Hypertension as the Major Cause of Stroke', pp. 9-12. doi: 10.1088/1674-1056/18/1/050.

Gold, S. M. et al. (2005) 'Hypertension and hypothalamo-pituitary-adrenal axis hyperactivity affect frontal lobe integrity', Journal of Clinical Endocrinology and Metabolism, 
90(6), pp. 3262-3267. doi: 10.1210/jc.2004-2181.

Goyal, R. and Sarwate, N. (2014) 'A correlative study of hypertension with lipid profile', Impact Journals, 2(2), pp. 143-150.

Hong, W.-H. S. (2010) 'Evidence-based nursing practice for health promotion in adults with hypertension in primary health care settings', ProQuest Dissertations and Theses, 4(4), pp. 226-245. Available at: http://search.proquest.com/docview/304782889?accountid=14701\%5Cnhttp://sfx.schol arsportal.info/ottawa?url_ver=Z39.88-

2004\&rft_val_fmt=info:ofi/fmt:kev:mtx:dissertation\&genre=dissertations+\%26+theses \&sid=ProQ:ProQuest+Dissertations+\%26+Theses+Global\&atitle=\&t.

Kementrian Kesehatan RI (2018) 'Hipertensi Membunuh Diam-diam, Ketahui Tekanan Darah Anda', Depkes.Go.Id, pp. 3-4. doi: 10.1360/zd-2013-43-6-1064.

Leone, A. (2015) 'Smoking and Hypertension', Journal of Cardiology and Current Research, 2(2), p. 86. doi: 10.15406/jccr.2015.02.00057.

$\mathrm{Lu}$, Y. et al. (2015) 'Lifestyle and risk of hypertension: Follow-up of a young prehypertensive cohort', International Journal of Medical Sciences, 12(7), pp. 605-612. doi: 10.7150/ijms.12446.

Nadra, K. (2017) 'Situasi Strategi Promosi Kesehatan Di Vico Indonesia, Tahun 2016 Vico Indonesia Health Promotion Strategy Situation in 2016', Jurnal Promkes, 5(1), pp. 93104.

Sarkar, T. and Pal Singh, N. (2015) 'Epidemiology and genetics of hypertension', Journal of Association of Physicians of India, 63(September 2015), pp. 61-68. doi: 10.4103/1011-4564.147251.

Wang, F. J., Tiwari, V. K. and Wang, H. (2014) 'Risk factors for hypertension in India and China: A comparative study', Health and Population: Perspectives and Issues, 37(12), pp. 40-49. doi: 10.1111/j.1438-8677.2012.00688.x. 